\title{
FABRICATION AND PROPERTIES OF SiC REINFORCED COPPER-MATRIX-COMPOSITE CONTACT MATERIAL
}

\author{
IZDELAVA IN LASTNOSTI S SiC UTRJENEGA KOMPOZITNEGA \\ MATERIALA NA OSNOVI BAKRA
}

\author{
Gozde Fatma Celebi Efe'1,2, Mediha İpek ${ }^{1}$, Sakin Zeytin ${ }^{1}$, Cuma Bindal ${ }^{1,2}$ \\ ${ }^{1}$ Sakarya University, Faculty of Engineering, Department of Metallurgy and Materials Engineering, Esentepe Campus, 54187 Sakarya, Turkey \\ ${ }^{2}$ Sakarya University, Biomedical, Magnetic and Semi Conductive Materials Research Center (BIMAS-RC), Esentepe Campus, 54187 Sakarya, Turkey \\ gcelebi@sakarya.edu.tr
}

Prejem rokopisa - received: 2015-07-01; sprejem za objavo - accepted for publication: 2015-07-28

This study aims at improving mechanical properties of electrical contacts through copper and copper-matrix silicon-carbidereinforced composites produced with powder metallurgy. Copper powder was produced with the cementation method. Pure copper and mixtures of copper with $3 \%$ of mass fraction of SiC powder were pressed with a uniaxial pressure of $280 \mathrm{MPa}$ and sintered at $700{ }^{\circ} \mathrm{C}$ for $2 \mathrm{~h}$ in an atmospheric environment. After the sintering, these compacts were immediately pressed at a load of $850 \mathrm{MPa}$ while the samples were hot. The characterization of the samples was made with microstructural investigations, relative-density experiments, electrical-conductivity and hardness measurements. XRD analyses revealed that there are no other phases besides $\mathrm{Cu}$ and $\mathrm{SiC}$ in the sintered samples. Electrical conductivity of pure copper was reduced from $91.7 \pm 1.8 \%$ IACS to $66.4 \pm 0.9 \%$ IACS but the hardness of pure copper was increased from $127 \pm 1.2 \mathrm{HVN}$ to $142 \pm 6.0 \mathrm{HVN}$ with the addition of $3 \%$ of mass fraction of SiC. Contact-count experiments were made with these samples to determine the contact performance for $(3000,6000,9000,12.000$ and 21.000) turns-on/off. The loss of the contact material increased with the increasing number of turn-ons, related with the increased copper oxide amount formed on the contact surfaces.

Keywords: $\mathrm{Cu}-\mathrm{SiC}$ composite, hardness, relative density, electrical conductivity, IACS, contacts test

Namen študije je izboljšanje mehanskih lastnosti električnih kontaktov iz bakra in kompozita bakra, ojačanega z delci silicijevega karbida, izdelanih iz prahov. Prah bakra je bil izdelan z metodo cementacije. Čisti baker in mešanice bakra s 3 masnimi odstotki SiC so bili enoosno stiskani s tlakom $280 \mathrm{MPa}$ in sintrani $2 \mathrm{~h}$ na $700{ }^{\circ} \mathrm{C}$ v atmosferskem okolju. Po sintranju so bili vzorci še vroči stisnjeni z obtežbo $850 \mathrm{MPa}$. Vzorci so bili karakterizirani s preiskavo mikrostrukture, z eksperimenti relativne gostote, $\mathrm{z}$ meritvijo električne prevodnosti in z meritvijo trdote. Rentgenska difrakcija je odkrila, da v sintranih vzorcih ni

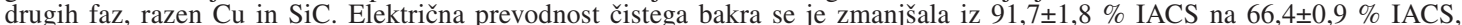
trdota čistega bakra se je povečala iz $127 \pm 1,2 \mathrm{HVN}$ na $142 \pm 6,0 \mathrm{HVN}$ z dodatkom 3 masnih odstotkov SiC. Preizkusi števila kontaktov so bili izvedeni s temi vzorci za določitev zmogljivosti kotaktov pri $(3.000,6.000,9.000,12.000$ in 21.000$)$ vklopih in izklopih. Izguba materiala kontakta se povečuje s povečanjem števila vklopov, kar je posledica povečanega obsega tvorbe oksida bakra na kontaktni površini.

Ključne besede: Cu-SiC kompozit, trdota, relativna gostota, električna prevodnost, IACS, preizkus kontaktov

\section{INTRODUCTION}

There are many electrical contact materials subject to relative motions and used in a variety of applications, such as electrical switches, contactors, circuit breakers, connectors, relays, chips in cards, voltage regulators, arcing tips and switch gears. ${ }^{1,2}$ Electrical contact materials used in these applications must have a good combination of wear strength, high electrical conductivity, and erosion and welding resistance. On the contrary, low electrical conductivity and wear resistance cause poor contact and arcing, and thus the contacts erode. An electric arc is the form of an electric discharge with the highest current density that takes place when contacts are in the process of establishing a current flow interrupting the flow of the current. Depending on high temperature and mass flow on the contact material surface, an erratic contact resistance and a material loss occur, thus the contact material surface is severely corroded and eroded. Hence, a contact material should have a high resistance to corrosion as well as a high arc-erosion resistance to maintain the contact integrity by having high electrical and thermal conductivity, a high melting point and also a certain strength. ${ }^{2,3}$ As copper has a high thermal conductivity, a low electrical resistance, a lower coefficient of thermal expansion (CTE) than aluminum and can easily be formed or machined into complicated lead frames or base plates, it is extensively used for cables, wires, electrical contacts and a wide variety of other parts that are required to pass electrical current. ${ }^{4,5}$

$\mathrm{Cu}$-based composites were feasible to be used as electrical-contact materials in relays, contactors, switches, circuit breaks and other switch-gear components. ${ }^{6}$ As SiC has a high thermal conductivity and offers good availability, low price and possible machinability, it can be used as a reinforcement in copper-based composites for high-performance heat-sink materials and packages. Dispersion of fine SiC particles improve the coppermatrix strength through impeding the dislocation movement and also prevent the grain growth of the copper 
matrix at high temperature so that the composites can maintain a relatively high strength at elevated temperature. ${ }^{3,7-9}$ In the present work, the effects of SiC particles on the electrical, mechanical and also contact performance of $\mathrm{Cu}-\mathrm{SiC}$ composites were investigated.

\section{EXPERIMENTAL DETAILS}

The copper powder used in this study was produced, with the cementation method, from $\mathrm{CuSO}_{4}$ solutions using metallic-iron powder. Cemented $\mathrm{Cu}$ powder and $3 \%$ mass fractions of $\mathrm{SiC}$ powder with a $99.5 \%$ purity and a $1 \mu \mathrm{m}$ particle size were mechanically mixed and cold pressed. The sintering of pure copper and copper $3 \%$ mass fraction of $\mathrm{SiC}$ was performed at $700{ }^{\circ} \mathrm{C}$ for $2 \mathrm{~h}$, embedded in the graphite powder. In order to increase the relative density and mechanical properties of test samples, they were hot pressed after the sintering. The presence of the phases formed within the sintered samples was determined with $\mathrm{X}$-ray diffraction using $\mathrm{Cu}-K_{\alpha}$ radiation with a wavelength of 1.5418 A over a $2 \theta$ range of $10-90^{\circ}$. The relative densities of the composites were measured with a method based on Archimedes' law.

The microstructure analysis of the composites was performed with a JEOL JSM-5600 model scanning electron microscope (SEM). The microhardness of both pure copper and the composite was measured with a Leica WMHT-Mod model Vickers-hardness instrument under an applied load of $50 \mathrm{~g}$. The measurements of electrical conductivity of the specimens were performed with a GE-model electrical-resistivity measurement instrument. The experimental set-up for the contact test consisted of a square 555-wave oscillator turning on/off the contactor, a counter and a contactor, on which the samples were mounted. The contact counter was adjusted to the desired number $(3000,6000,9000,12.000$ and 21.000) before the experiment. When the selected count number was reached, the operation was automatically ended. The electrical load over the counter was $1600 \mathrm{~W}$ (at $220 \mathrm{~V}$ ) for all the experiments. The experimental set-up used in this study is shown in Figure 1. The weight loss of the samples was determined. Subsequently, surface and oxide evaluations of the samples were carried out with SEM-EDS.

\section{RESULTS AND DISCUSSION}

SEM micrographs of $\mathrm{Cu}$ and the $\mathrm{SiC}$ reinforcement agent used in the experimental studies and the sintered $\mathrm{Cu}-3 \%$ of mass fractions of $\mathrm{SiC}$ composite are given in Figure 2. It is seen from Figure 2a that copper powder has a spherical shape and a particle size of $5 \mu \mathrm{m}$; and it is seen from Figure $\mathbf{2 b}$ that $\mathrm{SiC}$ particles have an angular and irregular shape, and a diameter of $1 \mu \mathrm{m}$. In Figure 2c light-grey areas indicate the $\mathrm{Cu}$ matrix and dark-grey and cornered shapes indicate the $\mathrm{SiC}$ reinforcement component.

XRD patterns of the $\mathrm{Cu}-3 \%$ of mass fractions of $\mathrm{SiC}$ composite consist of copper and $\mathrm{SiC}$ peaks (Figure 3 ). No oxide peak was observed in the XRD analysis of the $\mathrm{Cu}-3 \%$ of mass fractions of $\mathrm{SiC}$ composite sintered at $700{ }^{\circ} \mathrm{C}$ for $2 \mathrm{~h}$. The relative density, hardness and $\%$ IACS (the international annealed copper standard) of the samples are given in Table 1. The relative density of the sintered samples decreased with the addition of $\mathrm{SiC}$ because $\mathrm{SiC}$ particles behave as an obstacle for the $\mathrm{Cu}$ atom diffusion. On the contrary, the hardness was found to increase with the $\mathrm{SiC}$ addition. The $\mathrm{SiC}$ addition strongly impeded the plastic flow, causing the hardness of the $\mathrm{Cu}-\mathrm{SiC}$ composite to increase with the amount of reinforcing particles. It is known that the higher the relative density the higher is the electrical conductivity.
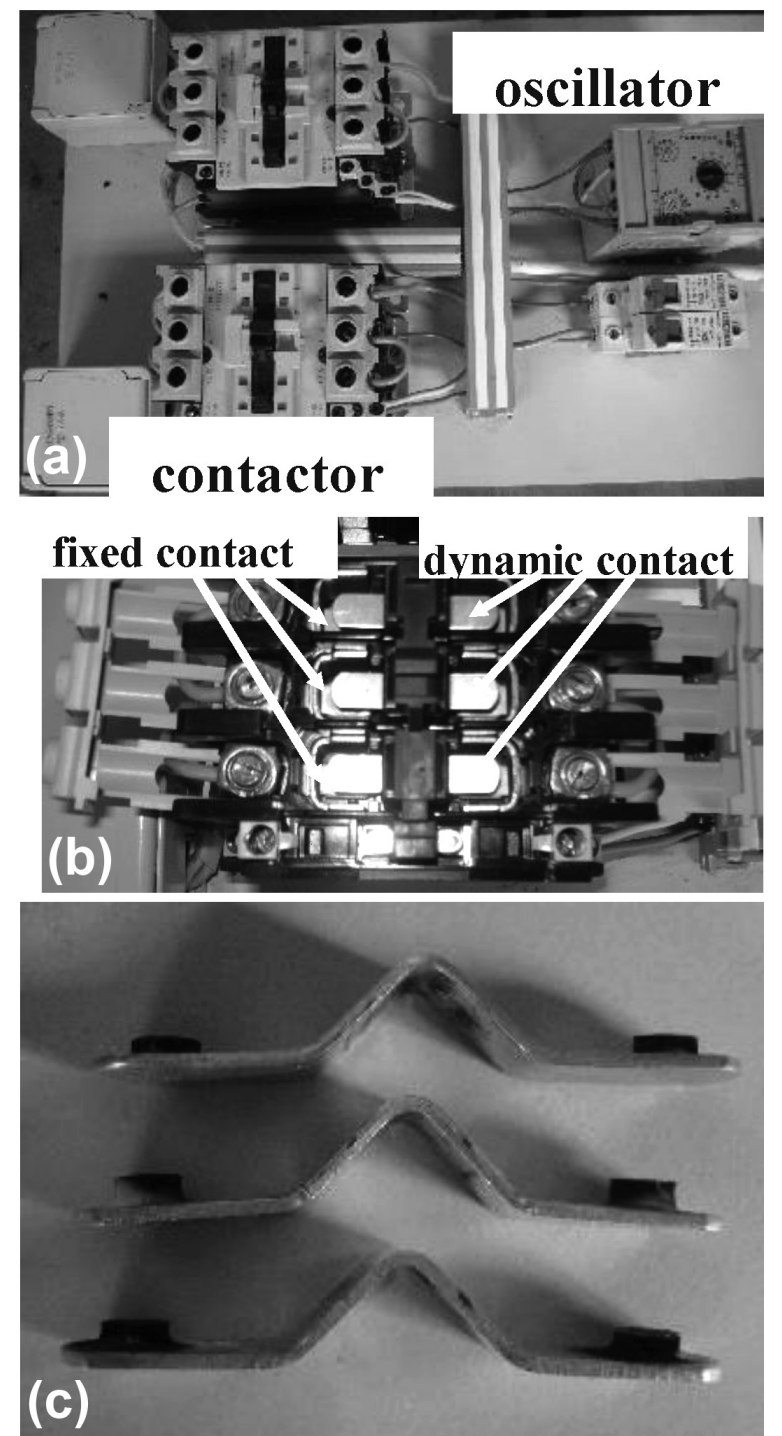

Figure 1: Images of: a) experimental set-up, b) contactor, on which samples were fixed, and contacts, c) dynamic contacts

Slika 1: Posnetki: a) eksperimentalnega sestava, b) kontaktorja, na katerem so pritrjeni vzorci in kontakti, c) dinamičnih kontaktov 
The electrical conductivity of the composites decreased with the increment in the $\mathrm{SiC}$ content because ceramic-based $\mathrm{SiC}$ forms a barrier to the motion of copper electrons, providing electrical conductivity.

Generally, the weight loss increased with the increasing contact count for both $\mathrm{Cu}$ and $\mathrm{Cu}-3 \%$ of mass fractions of $\mathrm{SiC}$ composite. But it is obvious that the material loss of the $\mathrm{Cu}-3 \%$ of mass fractions of $\mathrm{SiC}$ composite is higher than that of pure $\mathrm{Cu}$ (Figure 4).
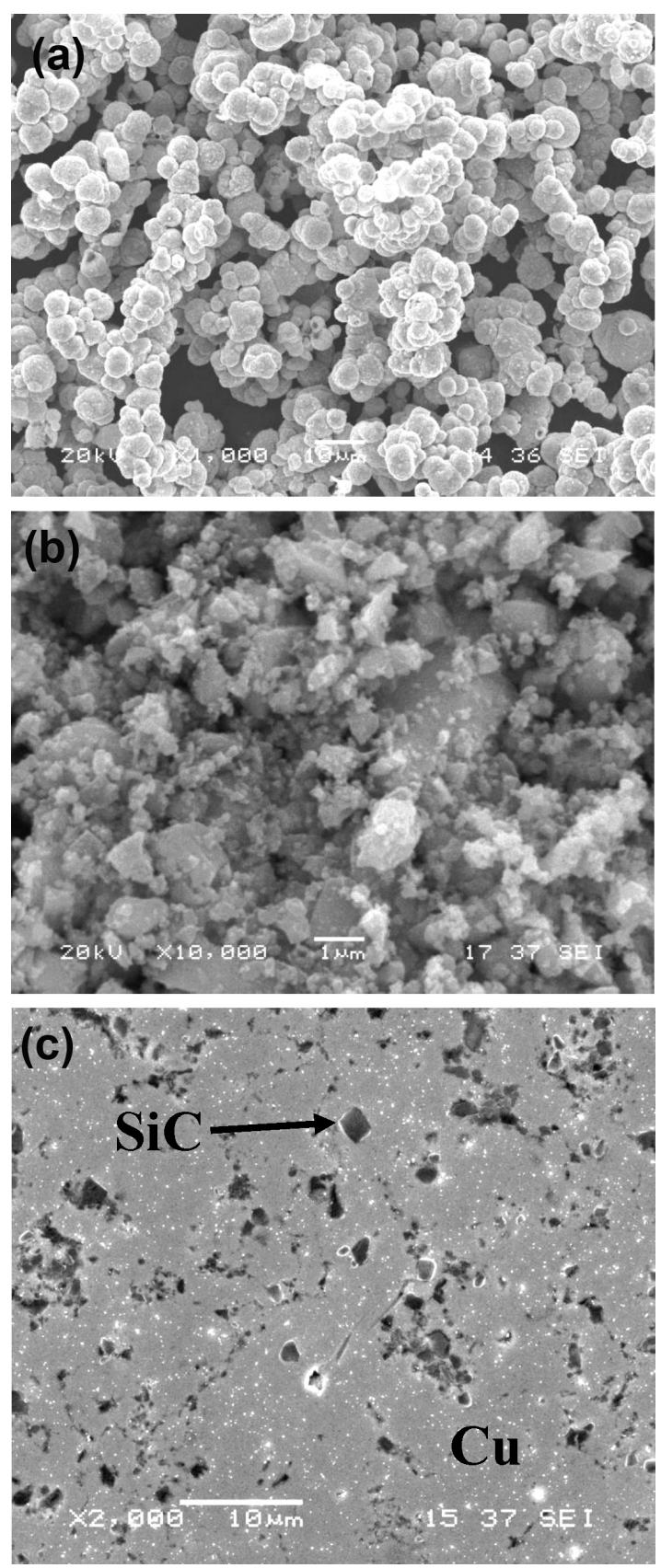

Figure 2: SEM micrographs of: a) copper powder, b) $\mathrm{SiC}$ particles and c) $\mathrm{Cu}-3 \%$ of mass fractions of $\mathrm{SiC}$ composite

Slika 2: SEM-posnetki: a) prah bakra, b) delci SiC in c) kompozit $\mathrm{Cu}-3 \%$ masnega deleža SiC

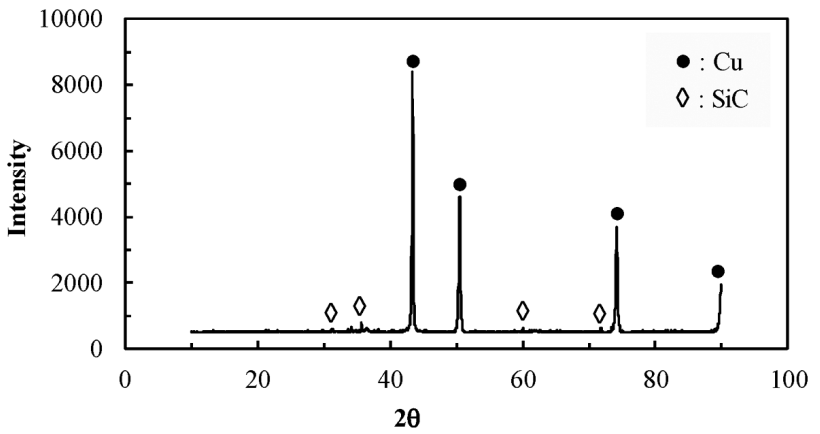

Figure 3: XRD patterns of $\mathrm{Cu}-3 \%$ of mass fractions of $\mathrm{SiC}$ composite sintered at $700{ }^{\circ} \mathrm{C}$ for $2 \mathrm{~h}$

Slika 3: Rentgenogram kompozita $\mathrm{Cu}-3$ \% masnega deleža $\mathrm{SiC}$, sintranega $2 \mathrm{~h}$ na $700{ }^{\circ} \mathrm{C}$

Table 1: Relative density, hardness and electrical-conductivity values of $\mathrm{Cu}$ and $\mathrm{Cu}-3 \%$ of mass fractions of $\mathrm{SiC}$ composite sintered at 700 ${ }^{\circ} \mathrm{C}$ for $2 \mathrm{~h}$

Tabela 1: Relativna gostota, trdota in električna prevodnost $\mathrm{Cu}$ in kompozita $\mathrm{Cu}-3 \%$ masnega deleža $\mathrm{SiC}, 2 \mathrm{~h}$ sintranega na $700{ }^{\circ} \mathrm{C}$

\begin{tabular}{|c|c|c|c|}
\hline Samples & $\begin{array}{c}\text { Relative density } \\
(\%)\end{array}$ & $\begin{array}{c}\text { Hardness } \\
(\mathrm{HV})\end{array}$ & $\%$ IACS \\
\hline $\mathrm{Cu}$ & $97.5 \pm 0.8$ & $127 \pm 1.2$ & $91.7 \pm 1.8$ \\
\hline $\begin{array}{c}\mathrm{Cu}-3 \% \text { of mass } \\
\text { fractions of } \mathrm{SiC}\end{array}$ & $92.3 \pm 1.1$ & $142 \pm 6$ & $66.4 \pm 0.9$ \\
\hline
\end{tabular}

SEM photographs of the sample surfaces after (3000, 6000 and 9000) turns-on/off are given in Figures 5 and 6. When $\mathrm{SiC}$ reinforced contact materials heat up, they have to absorb heat, cool down the contact and delay the arc formation; thus, their material loss is lower than that of pure copper. ${ }^{2}$ But it can be seen from the SEM micrographs that the surface of the $\mathrm{Cu}-3 \%$ of mass fractions of $\mathrm{SiC}$ composite is destroyed to a larger extent than the surface of pure $\mathrm{Cu}$; in addition, spherical formations, which got smaller with the increasing contact count number, were detected on the contact surfaces. With the increasing contact count number, deformed regions

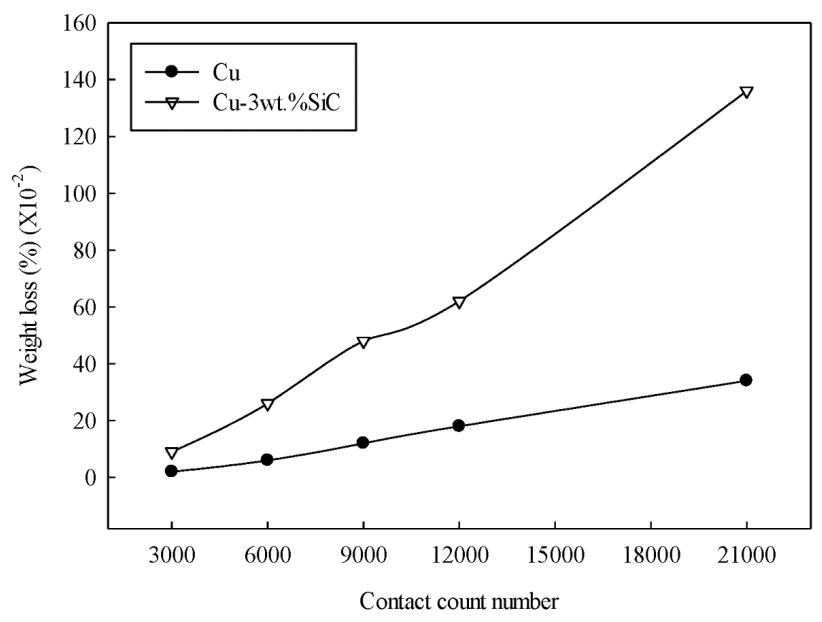

Figure 4: Weight loss of the contact via the contact count number Slika 4: Zmanjšanje teže kontakta v odvisnosti od števila vklopov 


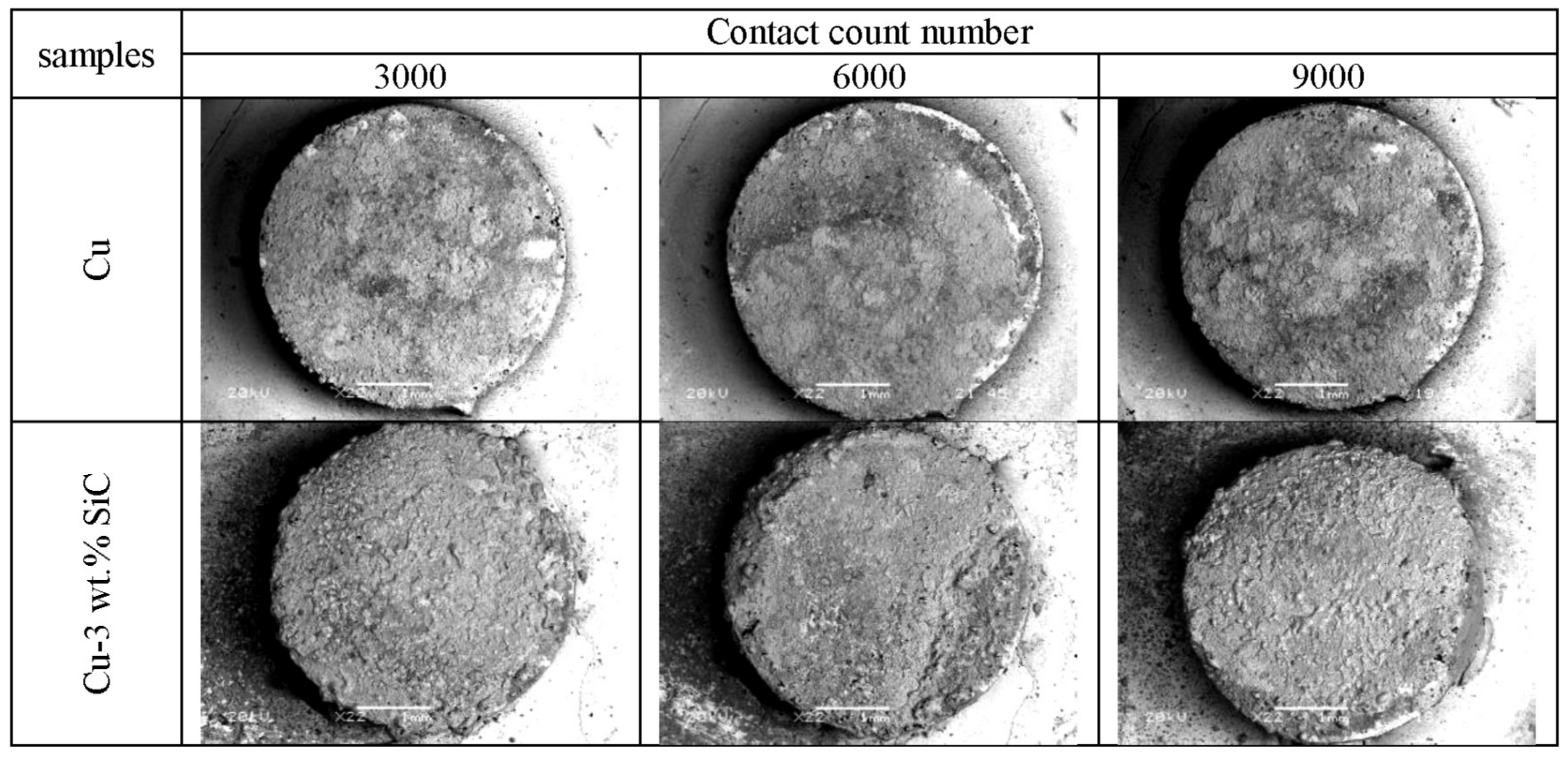

Figure 5: SEM micrographs of $\mathrm{Cu}$ and $\mathrm{Cu}-3 \%$ of mass fractions of $\mathrm{SiC}$ composite at a low magnification after 3000, 6000 and 9000 turns on/off Slika 5: SEM-posnetki Cu in kompozita Cu-3 \% masnega deleža SiC pri majhni povečavi, po 3000, 6000 in 9000 vklopih in izklopih

increased and local melting and smearing areas were formed.

EDS result taken from the surfaces of the contact samples are given in Figures $\mathbf{7}$ and $\mathbf{8}$. It was found that the weight loss increased with the increasing number of turns on/off in the contact-count experiments. Surface evaluations showed that oxide increased when the number of turns on/off increased and the arc formation got easier. O. Guler and E. Evin ${ }^{2}$ claimed that an increased copper oxide amount simplifies the arc formation between the contacts by increasing the contact resistance.
An increasing arc or a high resistance on a contact-material surface during a turn on/off heats up the contact surfaces. When the contact number is increased, particles on the surface become coarser. Brittle oxide layers on the contact material are broken by the impact force formed during turns on/off and removed from the surface. This causes a mass loss. This situation continues with a feedback mechanism. ${ }^{2}$ The EDS analysis of the sphere formations on the pure $\mathrm{Cu}$ surface after 9000 contacts show that these regions are $\mathrm{O}-$ and $\mathrm{Cu}$-rich areas (Figure 7). The EDS analysis shows that many $\mathrm{Cu}$-rich regions

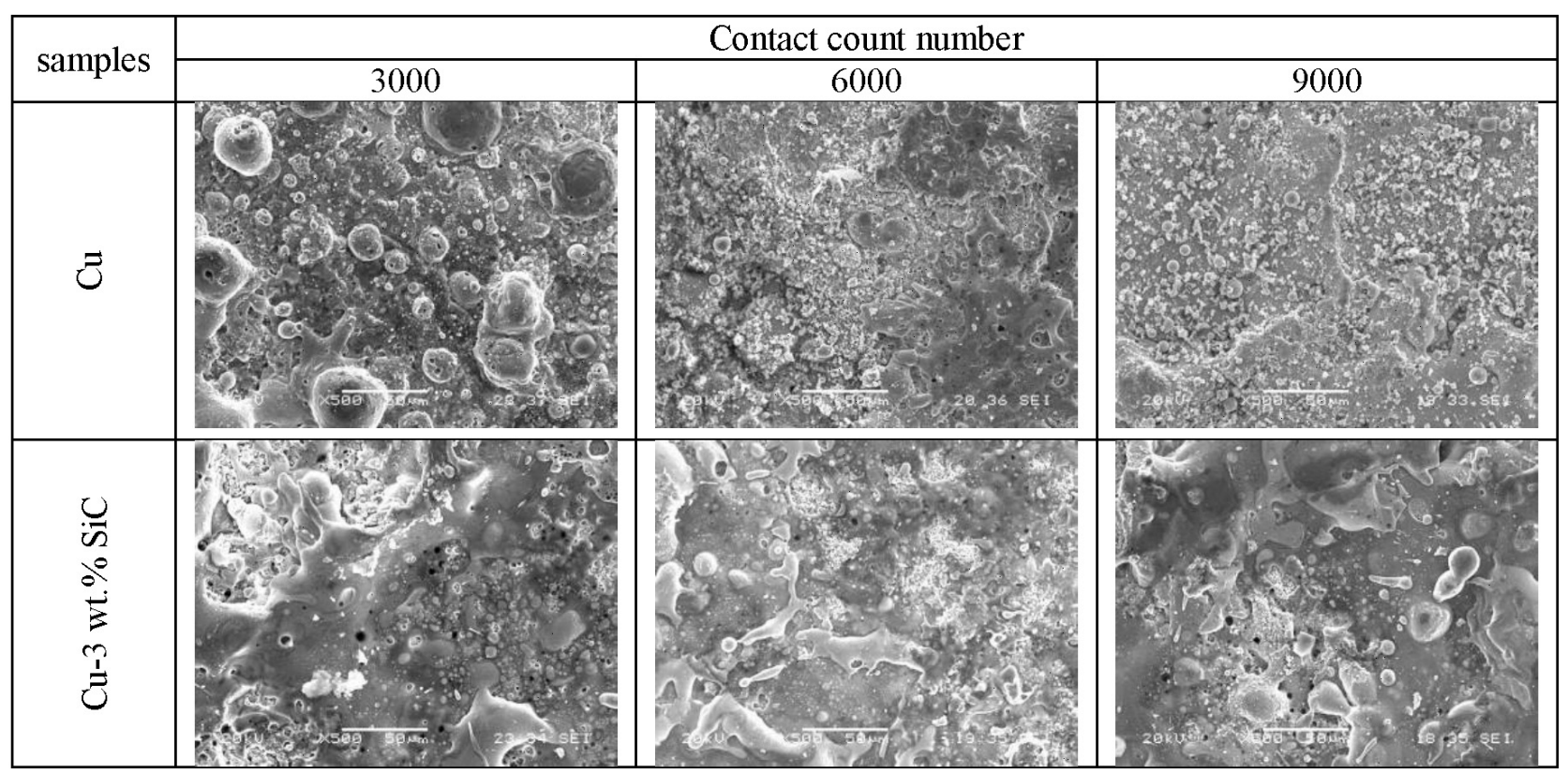

Figure 6: SEM micrographs of $\mathrm{Cu}$ and $\mathrm{Cu}-3 \%$ of mass fractions of $\mathrm{SiC}$ composite after 3000, 6000 and 9000 turns on/off Slika 6: SEM-posnetki Cu in kompozita Cu-3 \% masnega deleža SiC po 3000, 6000 in 9000 vklopih in izklopih 


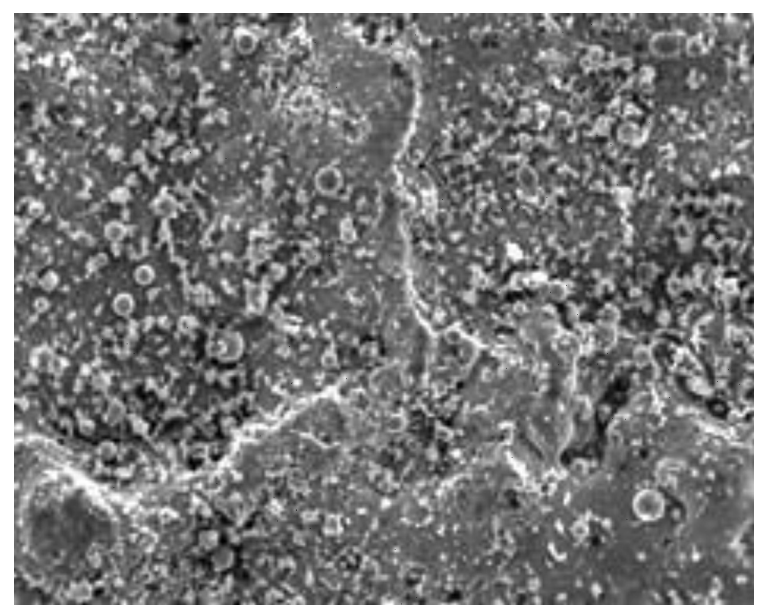

Figure 7: SEM micrograph and EDS analysis of $\mathrm{Cu}$ contact after 9000 turns on/off

Slika 7: SEM-posnetek in EDS-analiza Cu kontakta po 9000 vklopih in izklopih

\begin{tabular}{|c|c|c|c|c|c|c|}
\hline \multirow{2}{*}{$w / \%$} & \multicolumn{5}{|c|}{ Marks } \\
\cline { 2 - 7 } & 1 & 2 & 3 & 4 & 5 & 6 \\
\hline $\mathrm{C}$ & & 15.66 & & & & \\
\hline $\mathrm{O}$ & 16.25 & 17.68 & 23.900 & 20.87 & 17.87 & 1.641 \\
\hline $\mathrm{S}$ & & & 0.328 & & & \\
\hline $\mathrm{Fe}$ & 1.181 & 0.845 & 1.035 & 1.158 & 0.765 & 0.510 \\
\hline $\mathrm{Cu}$ & 82.56 & 65.79 & 74.737 & 77.96 & 81.35 & 97.85 \\
\hline
\end{tabular}

remain intact because they are under the average contact level. The remaining $\mathrm{Cu}$-rich areas show that the contact material can resist more turn on/off cycles.

In Figure 8, glassy regions rich with silicon, verified with the EDS analysis, are obvious. SiC particles probably oxidized with the increasing arc, the heat effect and/or the $\mathrm{Cu}$ and $\mathrm{Si}$ compounds formed. A. K. Kang and S. B. Kang ${ }^{10}$ indicated that $\mathrm{SiC}$ particles decompose into $\mathrm{Si}$ and $\mathrm{C}$ and merge with $\mathrm{Cu}$. T. Schubert et al. ${ }^{5}$ claimed that $\mathrm{SiC}$ is not stable at elevated temperatures and forms $\mathrm{Cu}-\mathrm{Si}$ solid solutions due to its decomposition. In Figure 8, Si-rich areas indicated with arrows have some bubbles and pores. These pores may result from gas reactions. It is thought that the gases in these bubbles leak towards the surface with the increasing heat/arc and bulge on the material surface. During the contact test, decomposed $\mathrm{C}$ reacts with $\mathrm{O}$, which results in $\mathrm{CO}_{2}$ and $\mathrm{CO}$ gas formations. ${ }^{10}$ The microcracks in the micrographs indicate that the contact surfaces are brittle and may be coated with a thin oxide film (Figure 8b).

\section{CONCLUSIONS}

A cemented $\mathrm{Cu}-\mathrm{SiC}$ composite was manufactured successfully with the powder-metallurgy method. The presence of $\mathrm{Cu}$ and $\mathrm{SiC}$ was verified with an XRD analysis. All of the samples manufactured had a remarkably high relative density. The hardness of the composite was increased with added SiC. It was observed that the
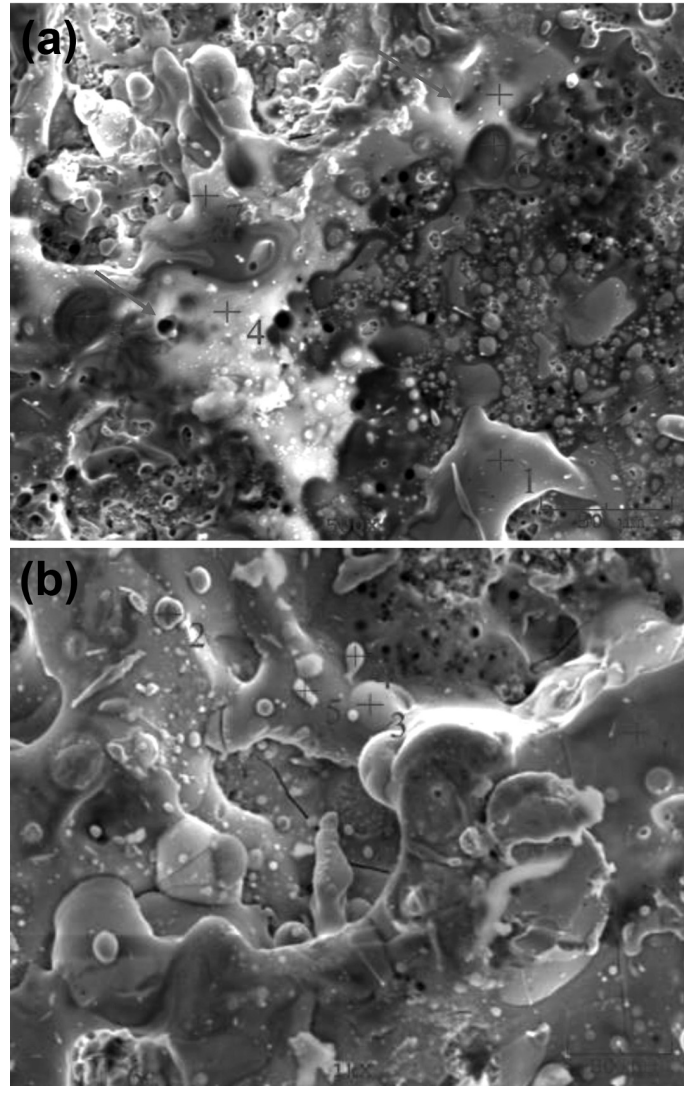

Figure 8: EDS analysis of $\mathrm{Cu}-3 \%$ of mass fractions of $\mathrm{SiC}$ composite after: a) 3000, b) 9000 turns on/off

Slika 8: EDS-analiza kompozita $\mathrm{Cu}-3$ \% masnega deleža $\mathrm{SiC}$ po: a) 3000 in b) 9000 vklopih in izklopih

\begin{tabular}{|c|c|c|c|c|c|c|c|}
\hline \multirow{2}{*}{$w / \%$} & \multicolumn{7}{|c|}{ Marks } \\
\cline { 2 - 9 } & 1 & 2 & 3 & 4 & 5 & 6 & 7 \\
\hline $\mathrm{C}$ & 2.364 & & \multicolumn{7}{|c|}{ Marks } \\
\hline $\mathrm{O}$ & 8.36 & 42.1 & 16.9 & 39.4 & 31.9 & 24.0 & 21.8 \\
\hline $\mathrm{Si}$ & & 16.1 & 4.39 & 17.8 & 11.9 & 6.00 & 11.2 \\
\hline $\mathrm{Fe}$ & 0.86 & 4.08 & 0.83 & 5.86 & 2.90 & 1.83 & 5.85 \\
\hline $\mathrm{Cu}$ & 88.4 & 37.6 & 77.8 & 36.8 & 53.1 & 68.1 & 60.9 \\
\hline \multirow{2}{*}{$w / \%$} & \multicolumn{7}{|c|}{} \\
\cline { 2 - 8 } & 1 & 2 & 3 & 4 & 5 & 6 \\
\hline $\mathrm{O}$ & 42.05 & 7.707 & 8.085 & 49.89 & 51.44 & 11.06 \\
\hline $\mathrm{Si}$ & 17.77 & 0.939 & 1.630 & 15.83 & 14.76 & 0.219 \\
\hline $\mathrm{Fe}$ & 8.527 & 1.152 & 1.024 & 6.112 & 5.813 & 0.226 \\
\hline $\mathrm{Cu}$ & 31.64 & 90.20 & 89.26 & 28.15 & 27.97 & 35.09 \\
\hline
\end{tabular}

electrical conductivity of the $\mathrm{Cu}-\mathrm{SiC}$ composite is in good agreement with the literature. During the contactcount experiments, the weight loss and oxidation increased with the increasing number of turns on/off for both samples. Also, the surface of the $\mathrm{Cu}-3 \%$ of mass fractions of $\mathrm{SiC}$ composite was destroyed to a larger extent than the surface of pure $\mathrm{Cu}$.

\section{Acknowledgment}

The authors thank expert Fuat Kayis for performing the XRD and SEM-EDS studies and special thanks are 
extended to technician Ersan Demir of the Sakarya University for assisting with the experimental studies. This work was conducted as a project supported by TUBITAK, with the contract number of 106M118.

\section{REFERENCES}

${ }^{1}$ J. Barrigaa, B. Fernandez-Diaza, A. Juarrosa, S. I. Ahmedb, J. L. Aranac, Microtribological analysis of gold and copper contacts, Tribology International, 40 (2007), 1526-1530, doi:10.1016/j.triboint. 2007.01.009

${ }^{2} \mathrm{O}$. Guler, E. Evin, The investigation of contact performance of oxide reinforced copper composite via mechanical alloying, Journal of Materials Processing Technology, 209 (2009), 1286-1290, doi:10.1016/j.jmatprotec.2008.03.034

${ }^{3} \mathrm{Z}$. Shi, M. Yan, The preparation of $\mathrm{Al} 2 \mathrm{O} 3-\mathrm{Cu}$ composite by internal oxidation, Applied Surface Science, 134 (1998), 103-106, doi:10.1016/S0169-4332(98)00223-2

${ }^{4}$ R. D. Joseph, Copper and copper alloys, ASM International Handbook

${ }^{5}$ T. Schubert, A. Brendel, K. Schmid, T. Koeck, L. Ciupinski, W Zielinski, T. Weibgarber, B. Kieback, Interfacial design of $\mathrm{Cu}-\mathrm{SiC}$ composites prepared by powder metallurgy for heat sink applications, Composites, 38 (2007), 2398-2403, doi:10.1016/ j.compositesa.2007.08.012
${ }^{6}$ R. Zhang, L. Gao, J. Guo, Temperature-sensitivity of coating copper on sub-micron silicon carbide particles by electroless deposition in a rotation flask, Surface and Coatings Technology, 166 (2003), 67-71, doi:10.1016/S0257-8972(02)00748-X

${ }^{7}$ J. Zhu, L. Liu, G. Hu, B. Shen, W. Hu, W. Ding, Study on Composite Electroforming of $\mathrm{Cu} / \mathrm{SiC}$ Composites, Materials Letters, 58 (2004), 1634-1637, doi:10.1016/j.matlet.2003.08.040

${ }^{8}$ R. Zhang, L. Gao, J. Guo, Effect of $\mathrm{Cu}_{2} \mathrm{O}$ on the fabrication of $\mathrm{SiCp} / \mathrm{Cu}$ nanocomposites using coated particles and conventional sintering, Composites: Part A, 35 (2004), 1301-1305, doi:10.1016/ j.compositesa.2004.03.02

${ }^{9}$ G. Celebi, M. Ipek, S. Zeytin, C. Bindal, An investigation of the effect of $\mathrm{SiC}$ particle size on $\mathrm{Cu}-\mathrm{SiC}$ composites, Composites: Part B, 43 (2012) 4, 1813-1822, doi:10.1016/j.compositesb.2012.01.006

${ }^{10}$ H. K. Kang, S. B. Kang, Thermal decomposition of silicon carbide in a plasma sprayed $\mathrm{Cu} / \mathrm{SiC}$ composite deposit, Materials Science and Engineering A, 428 (2006), 336-345, doi:10.1016/j.msea.2006.05. 054 